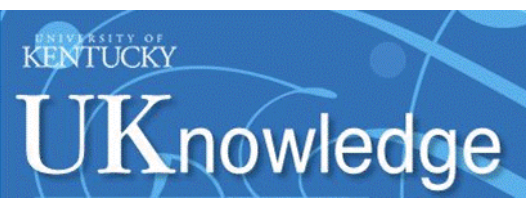

Kentucky Law Journal

\title{
The Hidden Costs of Lawyer Mobility: Of Law Firms, Law Schools, and the Education of Lawyers
}

Robert W. Hillman

University of California, Davis

Follow this and additional works at: https://uknowledge.uky.edu/klj

Part of the Legal Profession Commons

Right click to open a feedback form in a new tab to let us know how this document benefits you.

\section{Recommended Citation}

Hillman, Robert W. (2002) "The Hidden Costs of Lawyer Mobility: Of Law Firms, Law Schools, and the Education of Lawyers," Kentucky Law Journal: Vol. 91: Iss. 2, Article 3.

Available at: https://uknowledge.uky.edu/klj/vol91/iss2/3

This Article is brought to you for free and open access by the Law Journals at UKnowledge. It has been accepted for inclusion in Kentucky Law Journal by an authorized editor of UKnowledge. For more information, please contact UKnowledge@lsv.uky.edu. 


\title{
ARTICLES
}

\section{The Hidden Costs of Lawyer Mobility: Of Law Firms, Law Schools, and the Education of Lawyers*}

\author{
BY ROBERT W. HILLMAN"*
}

$\mathrm{T}$ hese comments address the consequences of nearly two decades of lawyer mobility and law firm destabilization and offer some thoughts on how lawyer mobility is, or at least should be, bringing into sharper focus the professional education mission of law schools.

In the thirty or so years that I have been in the legal profession, the values and assumptions underlying the practice of law have undergone profound changes. The young lawyer of my generation could look forward to joining a law firm, working hard for five to eight years, and, with a little luck, becoming a partner in the firm.

In the past, becoming a partner in a law firm was a little like getting married-both the firm and the lawyer approached the relationship as a long-term mutual commitment. For this reason, it was not at all uncommon to see a lawyer spend his or her entire career at a single law firm. Indeed, such a relationship was the expectation rather than the exception. This was the era of stable law firms.

An environment of law firm stability was supported by the culture of the profession as well as the state of the law. Firms generally avoided recruiting experienced lawyers and focused instead on developing their practices through the hiring and training of recent law school graduates. Mature lawyers had only limited opportunities to change firms. A firm focused on hiring bright but inexperienced lawyers so that it could impress upon its young associates the ways that firm liked to practice law. This reflected belief in a certain brand identity associated with professional

- Copyright (c) 2002 by Robert W. Hillman, Randall Park Lecture at the University of Kentucky College of Law, May 7, 2002.

** Professor of Law, University of California, Davis. 
practice. Each firm sought to differentiate its product from that of its competitors.

Stable firm membership was supported by lockstep compensation, a method of income allocation that has largely, although not entirely, disappeared from the scene. Under lockstep compensation, the longer a lawyer stays with a firm, the greater that lawyer's compensation. Combined with a culture that discouraged lawyer movement among firms, it is not surprising that law firms in an era of lockstep compensation enjoyed remarkable stability. You paid your dues and eventually you enjoyed the payback. Just be patient.

This is the environment that existed when I began to practice law. I was the forty-fourth lawyer to join my firm. The year was 1974, and the firm proudly boasted that no one had ever left the firm. More than a decade before John Grisham's bestselling thriller gave new meaning to such statements, ${ }^{1}$ the claim seemed innocent enough, if a bit naïve. I'm not sure if I was the first to leave the firm, but I can say with certainty that many lawyers left after I did, and continue to leave, thus assigning to the dustbin of history the now quaint notion of a long-term commitment to a law firm.

Of course, there is nothing unusual about the departures from my former firm. No law firm in the United States may safely assume that its future will be free of the type of heavy turnover. unknown when my generation entered law practice. Indeed, there are indications that the culture of lawyer mobility that originated in the United States is now beginning to take hold abroad. ${ }^{2}$ This is the era of lawyer mobility and law firm destabilization.

Such is the frequency of movement of lawyers among firms that, for good reason, the New York Court of Appeals has referred to the revolving door as a "modern day law firm fixture." $\mathrm{Law}$ firms and legal recruitment firms openly solicit lawyers with "portable clients," and the lawyer without a "book of business" will never be more than an employee of the firm. The Internet helps us see this clearly. Of the numerous web sites touching on the various facets of lawyer mobility, my personal favorite is lateralattorneys.com, ${ }^{4}$ which openly solicits for placement "partners with

${ }^{1}$ See JOHN GRISHAM, THE FIRM (1991) (account of an associate who came to regret accepting an offer that seemed too good to be true).

${ }^{2}$ See, e.g., Alexander J. Black, Canadian Lawyer Mobility and Law Society Conflict of Interest, 18 FORDHAM INT'L L.J. 118 (1994).

${ }^{3}$ Graubard Mollen Dannett \& Horowitz v. Moskovitz, 653 N.E.2d 1179, 1180 (N.Y. 1995).

${ }^{4}$ The site can be accessed at http://www.lateralattorneys.com (last visited Nov. 14, 2002). 
portables" and, if that is not lurid enough, offers to "assist entire practice groups in relocating to new firms."

For more than a decade, I have been writing about lawyer mobility trends, but I must confess that direct recruitments of this nature still surprise me with their boldness. Younger lawyers view my astonishment with some amusement and see nothing unusual about open solicitations of entire practice groups. This is the only environment that they have known, and the days before lawyer mobility became an integral part of the culture of the profession seem very long ago. Young lawyers may simply be unaware of the recency of the changes I am describing. If that is so, they need only ask older lawyers what law firms were like in the era when it was considered unethical, according to the $\mathrm{ABA}$, for lawyers to leave a firm and take clients with them: ${ }^{6}$

For just a moment, reflect on this rather remarkable and sudden change in the culture of the profession. To "repeat, there are many lawyers practicing today who began their careers when written ethics norms held that it was improper for a lawyer (let alone an entire practice group) to leave a firm and in the process take its clients.

The changes I am describing have paralleled restructurings taking place throughout society. Comparisons may be drawn to corporate takeovers and the development of a market for corporate control that achieved efficiencies through assaults on entrenched and nonresponsive managements. Throughout the country, professional and commercial firms are restructuring in ways that elevate efficiency over long-standing norms of loyalty and longevity. The developments in the legal profession that $I$ have been describing are simply an extension of private sector restructurings in the name of efficiency.

Indications of the change-to-come could be seen beginning in the mid1970 s in the form of increased competition throughout the legal profession. Law school enrollments surged. With the ranks of lawyers swelling, competition for clients became intense and traditional ethics norms that operated to restrain competition were relaxed quietly. Law firms embarked on growth strategies impossible to achieve solely on the basis of "promotion from within" policies. Firms abandoned lockstep compensation in

${ }^{5} I d$.

${ }^{6}$ See ABA Comm. on Prof'l Ethics, Formal Op. 300 (1961) (A restrictive covenant in contract with an association was unenforceable in part because it was unnecessary: "A former employee of a lawyer or a law firm would be bound by these canons to refrain from any effort to secure the work of clients of his former employer."). 
favor of rewarding more productive partners and lawyers with loyal client followings greater and greater percentages of their firms' revenue streams. Firms unwilling to change soon lost partners or entire departments in this new era of lawyer mobility and lateral hiring. The casualty of all of this sudden change was the rapidly antiquated notion of loyalty to the firm.

Although I do not intend to dwell in these remarks on the law of lawyer mobility, the role of law in encouraging and perhaps even supporting changes in the culture of the profession deserves at least passing mention. Since the late 1980s, an impressive body of case law has developed dealing with lawyer mobility issues. Unquestionably, courts have been quite supportive of trends in lawyer mobility.

Consider, for example, the first major case on lawyer mobility, the 1989 Cohen v. Lord, Day \& Lord opinion out of New York. ${ }^{7}$ In that case, Cohen, a tax partner of twenty years, left the Lord, Day \& Lord firm and joined another New York firm. Relying on a forfeiture-for-competition clause in its partnership agreement, Lord, Day \& Lord refused to pay Cohen the value of his partnership interest. Cohen sued the firm and prevailed. In striking down the firm's attempt to contractually restrain competition, a divided New York Court of Appeals observed that the clause "constitute[d] an impermissible restriction on the practice of law" that operated to undermine the interests of clients. ${ }^{8}$ With just a handful of exceptions, courts have followed the Cohen lead and voided direct and indirect contractual restraints on competition by withdrawing partners. ${ }^{9}$ Law, in short, supports lawyer mobility and the destabilization of law firms.

Some commentators, including the Chief Justice of the United States, seem nostalgic about the days in which lawyers remained loyal to their firms. ${ }^{10}$ On the whole, however, the development of lawyer mobility has yielded substantial positive results. I doubt that many lawyers would want to return to a world in which younger partners worked for years to support the lifestyle of older partners whose major contributions to their firms could only be expressed in the past tense. Competition creates opportuni-

\footnotetext{
${ }^{7}$ Cohen v. Lord, Day \& Lord, 550 N.E.2d 410 (N.Y. 1989).

${ }^{8}$ Id. at 411 .

${ }^{9}$ See generally ROBERT W. HILlMAN, HILLMAN ON LAWYER MOBILITY $§ 2.3$ (1998).

${ }^{10}$ See William H. Rehnquist, The Legal Profession Today, 62 IND. L.J. 151, 152 (1987) ("Institutional loyalty appears to be in decline. Partners in law firms have become increasingly 'mobile,' feeling much freer than they formerly did and having much greater opportunity than they formerly did, to shift from one firm to another and take revenue-producing clients with them.").
} 
ties, and the beneficiaries of change are the hard-working, talented lawyers with loyal clients. Successful lawyers are no longer trapped within their law firms. This is as it should be.

Still, there are costs associated with lawyer mobility. Unfortunately, because these costs are hidden, they have largely been ignored in the commentary on the changing culture of the profession.

What are the true costs of lawyer mobility and law firm destabilization? At one point, proponents of maintaining strong law firms by restraining lawyer mobility could argue that clients would certainly demand and very likely need stable law firms. In reality, however, destabilized law firms give clients more choice. Sophisticated clients typically "hire the lawyer and not the firm." They prefer an environment of competition. " Indeed, it seems very likely that law firm destabilization has lowered the cost of legal services, at least in the market serving corporate and institutional clients. That the voices of clients are absent from the chorus singing the blues of lawyer mobility should surprise no one.

Who, then, are the casualties of recent lawyer mobility trends? Certainly, many older lawyers without substantial client portfolios have suffered greatly and undoubtedly yearn for a return to lockstep compensation systems that reward lawyers for longevity with a firm. This was, after all, the deal promised to them when they entered the profession and joined their firms. Demotions, layoffs, and assorted other indignities have faced lawyers who for whatever reason are unable to command the loyalties of portable clients. Although these are sad cases, they may simply represent a reassessment of the value of legal skills in an environment in which lawyers as technicians are, in a word, fungible.

Of greater concern is the plight of lawyers now entering the profession. A growing number of law schools are subordinating professional training to academic and social reform goals. They have done so assuming that law firms will provide the training necessary for recent entrants to the profession. Under this view, law schools provide the theoretical foundation or social conscience and law firms develop more practical skills through the training they provide in an extended period of post-graduate education.

The problem is that lawyer mobility serves as a disincentive for investment by firms in the training and development of their lawyers. Escalating salaries and associate turnover require that entry-level attorneys generate substantial billable hours from the day they walk in the door and

${ }^{11}$ For a discussion of this point, see generally Robert W. Hillman, Loyalty in the Firm: A Statement of General Principles on the Duties of Partners Withdrawing from Law Firms, 55 WASH. \& LEE L. REV. 997, 1010-11 (1998). 
begin consuming expensive overhead. Mentoring and other inefficient activities, such as simply allowing associates to observe experienced lawyers at work, are luxuries few firms can afford. To be sure, firms do train their associates in a sense, but the emphasis is on an immediate return on dollars invested in training rather on than the long-term development of the lawyers being educated. Thus, when it occurs, training focuses on structured, formalized programs emphasizing skills immediately needed in the practice.

It may be instructive to reflect on how the associate development activities of law firms have changed over the years. Here, we must rely on anecdotal evidence rather than hard data, which is virtually nonexistent. Lawyers of my generation may recall the accounts of older lawyers, some of whom never attended law school, who spoke of apprentice-type training where they "carried the briefcases" of experienced lawyers and learned how to practice through mentoring and observation. They often would speak with affection of the older lawyers who would spend hours talking with them about law, strategy, ethics, and whatever else remotely related to the cases they were handling. By modern standards, this training was clearly inefficient.

By the time my generation entered the profession, law firms had proliferated and assumed significant training responsibilities. Firms accepted the fact that associates would not be "profitable" until at least their third or fourth years, but this was manageable because associate turnover was relatively low and, for the most part, controlled. The shortterm subsidization of inexperienced lawyers would easily be repaid as the lawyers developed into mature professionals. The system was highly rational even though it may seem inefficient by more modern measures of firm performance.

Lawyers of my generation were not under early pressure to make long term, irreversible career choices. For example, many large and mediumsized firms offered rotation programs for newly-hired law school graduates. Typically, a rotation program allowed the inexperienced associate to spend time in up to four practice areas over an extended period, normally two years. Then, with the benefit of some significant experience, the lawyer could decide to specialize in tax, or litigation, or real estate, or whatever other practice area the firm may have offered. Some lawyers declined the rotation option, preferring instead to specialize immediately. But many associates were less sure about practice choices and greatly benefited from the broad perspectives derived from exposure to various practice areas and lawyering styles.

By modern standards, rotation programs are inefficient and, not surprisingly, largely have disappeared. To be sure, some firms still claim 
to offer rotation programs, but the limitations of the offers become apparent on a closer examination of what the firms actually are doing. One of the preeminent firms in the country, for example, boasts of a training program keyed to rotation of associates, but on a reading of the fine print it becomes clear that the entire rotation occurs within a single department of the firm. ${ }^{12}$ At this firm, as well as at others, one can only hope that the recent law school graduates joining the firm have sufficient information to make longterm specialization choices.

Further evidence of declining investment in lawyer development is seen in the demise of traditional mentoring within firms. When properly conducted, mentoring may involve extended periods in which the new lawyer simply observes the experienced lawyer at work on such disparate matters as negotiations, depositions, and client meetings. Even more importantly, effective mentoring requires the experienced lawyer to take the time to instruct the associate on the art and skill of practicing law effectively. To be sure, mentoring of this nature always was hit-and-miss, and not all associates were fortunate enough to have good mentors. But when it happened, it worked very, very well. ${ }^{13}$

Today, mentoring is not widely used or even tolerated because its costs cannot easily be passed on to clients. ${ }^{14}$ Firms may claim to support mentoring, but they do so through formalized and structured programs. Today, the typical pattern is for a firm to assign mentoring responsibilities to its more senior lawyers. Not surprisingly, the "fit" between mentor and mentee may leave much to be desired. Even assuming compatibility, an environment stressing the maximization of billable hours by junior and senior lawyers alike is not conducive to inefficient activities such as mentoring.

${ }^{12}$ See Cravath, Swaine \& Moore, Legal Recruiting, at http://www.cravath.com/ enter.html (last visited Oct. 16, 2002) ("Under our system of development and training, we rotate each associate to different partners or groups of partners within one of our four departments selected by the associate-Corporate, Litigation, Tax, or Trusts \& Estates.").

${ }^{13}$ For an excellent account of effective mentoring, see Patrick J. Schiltz, Legal Ethics in Decline: The Elite Law Firm, the Elite Law School, and the Moral Formation of the Novice Attorney, 82 MINN. L. REV. 705, 721-22 (1998).

14 The Nebraska State Bar Association has a mentoring program designed to ease the transition into the practice. See Nebraska State Bar Association, Member Services, at http://www.nebar.com/memberinfo/services/mentor/index.htm (last visited Oct. 16, 2002). Mentors must have at least ten years of practice experience. The program serves an important need but is limited by the fact that mentor and mentee are not within the same firm and do not jointly provide legal services. Id. 
Although it is tempting to describe firms of the past as less profit driven than contemporary firms and thus more able and willing to engage in costly training activities, we must be careful not to be too naïve in this regard. One of the dirty little secrets of the past was the ability of firms to pass on a wide array of costs, including mentoring and training costs, to unsuspecting and trusting clients. ${ }^{15}$ But as clients became more sophisticated, they resisted subsidizing the training functions of law firms. With this change, mentoring and related training activities were no longer the beneficiaries of involuntary client subsidies. Without those subsidies, the activities could not survive in a new era emphasizing law firm profit margins and profitability-per-partner rankings.

I should make it clear that I am not recommending implementation of intensive mentoring programs in law firms. The nature of mentoring is such that it is not likely to succeed when implemented by managerial directive. Moreover, it is not at all clear that mentoring would be fairly apportioned across a group of young lawyers far more diverse than at any time in the past. Rather than endorsing it for present times, I am simply using mentoring to illustrate the changing environment of training within law firms. Mentoring is expensive and there may exist more effective ways to use limited training resources. But what those more effective ways may be is an unasked question and a largely irrelevant one given the diminishing resources devoted to the training of new lawyers.

To be sure, it would be an exaggeration to suggest that the decline in the law firm's role in the training and development of lawyers is attributable only to lawyer mobility. Other factors also have undermined training and development activities. Most notable in this regard is escalating compensation for entry-level lawyers, a trend that partially but not perfectly correlates with steady increases in the student debt levels of law school graduates. High associate salaries squeeze profit margins and invite management practices designed to improve the profitability of associates. Although the environment is conducive to training aimed at improving an associate's ability to accomplish the tasks at hand, longer term development activities are not cost effective, particularly when there is no assurance that the associate will remain with the firm for more than a year or two, if that long.

The core problem is one of dwindling resources devoted by law firms and law schools to the training and development of young lawyers. ${ }^{16}$ No

${ }^{15}$ See, e.g., Schiltz, supra note 13, at 742 (noting the relaxed monitoring of law firm expenses by clients during the 1980s).

${ }^{16}$ See generally Robert W. Hillman, Professional Partnerships, Competition, and the Evolution of Firm Culture: The Case of Law Firms, 26 J. CORP. L. 1061 (2001); Thomas Disare, A Lawyer's Education, 7 MD.J. CONTEMP. LEGAL ISSUES 359 (1996). 
one can argue that law practice is simpler today than it was in the past. To the contrary, it is apparent that the challenges facing lawyers are greater than they ever have been. Early in his or her career a lawyer needs to consider such basic questions as how to resolve conflicts between truth and advocacy, the role of candor in negotiations, correct responses to client or attorney misconduct, the meaning and importance of document integrity, and what, if any, compromises are appropriate in the quality of an attorney's work product in order to meet the pressures of time and cost. We are fond of talking about the globalization of law practice, but how many classes even raise the issue of whether a lawyer is obligated to respect foreign law?

I am not suggesting that these are the most important questions to put before law students, but I do believe that they illustrate the types of issues deserving of development if law schools are to discharge even minimal responsibilities in the area of professional education. I question whether many law schools, especially those that seek "elite" status, are emphasizing issues of character and values, not to mention exploring what it means to be a professional. Many lawyers entering the profession today will not receive substantial assistance from law schools in forming a broad perspective on lawyering that can serve as a foundation for professional development over the decades to come.

Consider the extent to which law students are exposed to the serious issues of ethics that lawyers face at critical moments in their careers. ${ }^{17}$ Many academics seem unwilling to integrate ethics issues into substantive courses in such fundamental areas as criminal law, civil procedure, and contracts. They may justify the inattention to matters of ethics because of the existence of a separate and mandatory ethics course in the curriculum. Although every law school has an ethics course, the instruction too often is minimalist at best and generally is keyed to assisting students in passing the ethics portion of bar examinations. ${ }^{18}$ This should be recognized for what it is-bar preparation, not fundamental training in ethical issues facing

\footnotetext{
${ }^{17}$ For an excellent treatment of this issue, see MARY ANN GLENDON, ANATION UNDER LAWYERS 222-29 (1994).

${ }^{18}$ Cf. Deborah L. Rhode, The Professional Responsibilities of Professors, 51 J. LEGAL EDUC. 158, 158 (2001)("Although virtually all law schools preach values of professional responsibility and public service, few make any systematic or sustained effort to institutionalize them in practice. Issues of legal ethics are generally relegated to a specialized course and are missing or marginal elsewhere in the curriculum.").
} 
practicing lawyers. Where is the discussion of the value of a reputation and the importance of doing the right thing even when no one else is looking?

Of course, law schools will also point to the development of clinical programs and "skills training" courses as signs of their commitment to professional education. ${ }^{19}$ In particular, the growth of clinical programs may seem to be moving law schools closer to the medical school model, where clinical education is an integral part of the curriculum. ${ }^{20}$ Any seeming similarities between medical and legal education, however, do not survive close scrutiny. In law schools, clinical education and skills courses lack status and constitute a relatively small part of the educational program. Moreover, their very existence may serve to remove the pressure on teachers of more substantive (academic) courses to treat their subjects as important components of professional education.

And so what is to be done?

In a perfect world that would allow us to start from scratch, we certainly would not come up with a system for educating and training lawyers even remotely resembling the one we have today. We would reexamine the traditional, three-year law school curriculum that has been in place longer than any of us can remember. ${ }^{21}$ We would strike a sensible balance between the academic and professional training activities of law schools. We would consider post-graduate apprenticeship programs jointly overseen by firms and schools to facilitate a well-conceived transition from school to practice. And we would do everything possible to lower the cost of a legal education so that heavy debt does not force recent graduates to take the highest paying position without regard to training and development issues.

The point on student debt bears special emphasis. The norm today is for a student to incur $\$ 80,000$ of debt for a legal education. ${ }^{22}$ This, of course, is on top of a significant base of undergraduate debt that many

${ }^{19}$ An example of such a program can be found at $\mathrm{http}: / / \mathrm{www}$. law.harvard.edu/ academics/clinical (last visited Jan. 23, 2003).

${ }^{20}$ See, e.g., Lawrence M. Grosberg, Medical Education Again Provides a Model for Law Schools: The Standardized Patient Becomes the Standardized Client, 51 J. LEGAL EDUC. 212, 213 (2001) ("Clinical education-learning by doing and learning by observing doctors and teachers practicing medicine . . . has long been an integral part of the medical school curriculum.").

${ }^{21}$ The ABA accreditation requirements for a Program of Legal Education are accessible at http://www.abanet.org/legaled/standards/chapter3.html (last visited Jan. 23, 2003).

${ }^{22}$ For data on the debt loads of law graduates, see Hillman, supra note 16 , at 1082. 
students bring to their first class in law school. Lawyers and academics of my generation may not fully appreciate the fact that the price of education since we graduated has risen much faster than the overall rate of inflation. There is no reason to believe that the alarming trends in place with respect to undergraduate debt do not extend to law school debt as well. A recent report outlines the rapid rise in undergraduate debt levels and notes that an increasing percentage of college graduates enter the job force with unmanageable levels of debt. ${ }^{23}$ The report adds:

Over the past ten years, after adjusting for inflation, the median family income increased by $12 \%$, while the average tuition and fees at four-year public institutions increased by $40 \%$ and that at four-year private schools by $33 \%$. As family income in this country becomes more stratified, tuition as a percentage of family income will continue to increase, particularly for low-income students, amplifying the average student's debt burden. ${ }^{24}$

To this, I would simply add that the very substantial additional debt burdens that students must incur in order to secure a professional degree in law would seem to require some correlation between the education they are financing and its relationship to their development as lawyers.

The "cutting edge" in legal education most assuredly has nothing to do with issues affecting the profession. Although some law schools justly pride themselves on the quality and affordability of the professional education they provide, a growing and far noisier group of law schools seek status for their academic mission by consciously distancing themselves from the professional education model. There is little incentive for deans or faculty to commit meaningful energies and resources to the professional development of lawyers rather than to academic research and social reform agendas. In the law school world, prestige cannot be gained by success in professional education.

Even if some schools were bold enough to be innovative and responsive to changes in the profession, they would face substantial resistance to any departures from the existing norms of legal education. ${ }^{25}$ Most notable in

${ }^{23}$ See Tracey King \& Ellynne Bannon, The Burden of Borrowing: A Report on the Rising Rates of Student Loan Debt (The State PIRG's Higher Education Project, Washington, D.C.), Mar. 2001, available at www.pirg.org/highered/ BurdenofBorrowing.pdf.

${ }^{24}$ Id. at 6 (citing The College Board, 2001, Trends in College Pricing).

${ }^{25}$ See Deborah L. Rhode, Legal Scholarship, 115 HARV. L. REV. 1327, 1355 (2002) (noting that "accreditation and informal systems of ranking have reinforced a 'one-size-fits-all' model of law schools that discourages innovation and specialization.") (footnote omitted). 
this regard are the pressures emanating from an accreditation process that operates to maintain the status quo and discourage innovation. This is supported by published law school rankings reflecting a unitary model of legal education by measuring the worth of all law schools by reference to the standards of the elite few. ${ }^{26}$ In an environment that claims to celebrate diversity, there is a monotonous sameness among law schools.

Although the debate over the professional versus academic orientation of law schools is nothing new, the questions it poses are assuming an urgency unknown in the past. Law schools no longer have the luxury of relying on law firms to fill the gaps in foundational professional education. If issues of lawyer development and training are of secondary importance to law schools, then perhaps we have a significant problem of institutional accountability that needs to be addressed.

But that is for another time, and another Article. For present purposes, I am content to highlight one of the more significant but hidden costs of the destabilization of law firms resulting from lawyer mobility. No longer may law firms be relied upon to provide fundamental postgraduate education as well as an orderly transition into the practice of law. Unless we are willing to assume that these were unimportant functions being performed by firms of the past, we will sooner or later have to address the question-who should pick up the slack? The answer, I suggest, is obvious.

${ }^{26}$ The widely used U.S. News rankings are accessible at http://usnews.com/ usnews/edu/grad/rankings/law/lawindex.htm (last visited Jan. 23, 2003). 